\title{
Hydration Activity and Carbonation Characteristics of Dicalcium Silicate in Steel Slag: A Review
}

\author{
Hao Na (D), Yajun Wang, Xi Zhang *, Junguo Li *, Yanan Zeng and Pengyao Liu \\ College of Metallurgy and Energy, North China University of Science and Technology, 21 Bohai Road, \\ Tangshan 063210, China; 18332717355@163.com (H.N.); wangyjgg@gmail.com (Y.W.); \\ zengyanan@ncst.edu.cn (Y.Z.); lpy8135834887@163.com (P.L.) \\ * Correspondence: zhangxi19851985@163.com (X.Z.); lijg99@163.com (J.L.)
}

Citation: Na, H.; Wang, Y.; Zhang, X.; Li, J.; Zeng, Y.; Liu, P. Hydration Activity and Carbonation Characteristics of Dicalcium Silicate in Steel Slag: A Review. Metals 2021, 11, 1580. https://doi.org/10.3390/ met11101580

Academic Editors: Yadir Torres Hernández and Timo Fabritius

Received: 26 July 2021

Accepted: 30 September 2021

Published: 4 October 2021

Publisher's Note: MDPI stays neutral with regard to jurisdictional claims in published maps and institutional affiliations.

Copyright: (c) 2021 by the authors. Licensee MDPI, Basel, Switzerland. This article is an open access article distributed under the terms and conditions of the Creative Commons Attribution (CC BY) license (https:/ / creativecommons.org/licenses/by/ $4.0 /)$.
Abstract: Dicalcium silicate is one of the main mineral phases of steel slag. Ascribed to the characteristics of hydration and carbonation, the application of slag in cement production and carbon dioxide sequestration has been confirmed as feasible. In the current study, the precipitation process of the dicalcium silicate phase in steel slag was discussed. Meanwhile, the study put emphasis on the influence of different crystal forms of dicalcium silicate on the hydration activity and carbonation characteristics of steel slag. It indicates that most of the dicalcium silicate phase in steel slag is the $\gamma$ phase with the weakest hydration activity. The hydration activity of $\gamma-C_{2} S$ is improved to a certain extent by means of mechanical, high temperature, and chemical activation. However, the carbonation activity of $\gamma-C_{2} S$ is about two times higher than that of $\beta-C_{2} S$. Direct and indirect carbonation can effectively capture carbon dioxide. This paper also summarizes the research status of the application of steel slag in cement production and carbon dioxide sequestration. Further development of the potential of dicalcium silicate hydration activity and simplifying the carbonation process are important focuses for the future.

Keywords: steel slag; dicalcium silicate; hydration activity; carbonation properties; comprehensive utilization

\section{Introduction}

According to the statistics of the World Steel Association, the global crude steel output reached 1.864 billion tons in 2020, and the proportion of China's crude steel output increased from $53.3 \%$ in 2019 to $56.5 \%$, reaching 1.053 billion tons [1]. As a by-product of steelmaking, steel slag production is about $12-20 \%$ of crude steel output [2], and the annual production of steel slag in our country is more than 100 million tons. At present, China lacks mature steel slag processing technology and necessary application standards. After steel enterprises carry out magnetic separation and separation of steel slag, a small amount of the tailings are used for road construction, cement production, while most of the tailings are piled up and discarded.Steel slag storage not only occupies a lot of land but also poses a severe threat to the ecological environment [3]. Up to now, the utilization rate of steel slag in Chinese steel enterprises has only been $29.5 \%$, which is far less than that in the United States (84.4\%), Europe (87.0\%), and Japan (98.4\%) [4]. As an energy-carrying resource, the treatment and comprehensive utilization of steel slag can effectively solve the problems of excessive land occupation, consumption of primary resources, and carbon emissions [5].

The types of steel slag produced by different smelting methods can be divided into basic oxygen furnace slag (BOF slag), electric arc furnace slag (EAF slag), argon oxygen decarburization stainless steel slag (AOD slag), and ladle metallurgy furnace slag (LMF slag), etc. [6]. According to the basicity of steel slag $\left(\mathrm{CaO} /\left(\mathrm{SiO}_{2}+\mathrm{P}_{2} \mathrm{O}_{5}\right)\right)$, it can be divided into low basicity slag (basicity < 1.8), medium basicity slag (basicity is 1.8 2.4), and high basicity slag (basicity > 2.4) [7]. No matter the classification standard is, the type, or basicity, the mineral composition of steel slag contains a certain amount of dicalcium silicate phase. 
When the basicity of steel slag is in the range of 1.6 2.4, it is even called dicalcium silicate slag [8-11].

Dicalcium silicate material has the advantages of long-term strength, good corrosion resistance, low preparation temperature, low carbon dioxide emission, and the like during hydration, but the disadvantages of slow hardening speed, low early strength, and low hydration heat release limit its application in hydration properties [12]. The production of materials such as Portland clinker releases a large amount of carbon dioxide (about 0.8 tons of carbon dioxide per ton of Portland clinker produced [13] and 1.86 tons of carbon dioxide per ton of steel produced [14]), so adding slag to Portland cement is a way to alleviate the global greenhouse effect [15]. The carbonation properties of materials rich in dicalcium silicate can not only absorb carbon dioxide in the atmosphere, but also the carbonation products (calcium carbonate, etc.) have good mechanical properties. In recent years, the research on mineral materials with dicalcium silicate as the core to retain carbon dioxide has become increasingly concerned [16,17].

Dicalcium silicate is the main mineral phase of steel slag. The hydration activity and carbonation characteristics of the dicalcium silicate phase provide more possibilities for the comprehensive utilization of steel slag. Aiming at dicalcium silicate minerals in steel slag, this paper focuses on the research status of hydration activity and carbonation characteristics of dicalcium silicate in steel slag at home and abroad in recent years, as well as the research progress of its application in cement production and carbon dioxide sequestration, in order to provide reference and enlightenment for the next step of comprehensive utilization of steel slag.

\section{Crystal Structure and Activity of Dicalcium Silicate}

Dicalcium silicate $\left(\mathrm{Ca}_{2} \mathrm{SiO}_{4}, \mathrm{C}_{2} \mathrm{~S}\right)$ has an island silicate structure, and the crystal structure has a three-dimensional spatial structure formed by connecting $\left[\mathrm{SiO}_{4}\right]$ tetrahedrons through $\left[\mathrm{CaO}_{x}\right.$ ] polyhedrons [18]. There are five different crystal forms of $\mathrm{C}_{2} \mathrm{~S}$ crystal at different temperatures: $\gamma, \beta, \alpha_{L}^{\prime}, \alpha_{H}^{\prime}$, and $\alpha$. The relationship between the evolution of $\mathrm{C}_{2} \mathrm{~S}$ crystal form and the change of temperature is shown in Figure 1 [19]. The essence of its crystal transformation is the migration of $\mathrm{Ca}$ atoms in the crystal structure and the rotation of $\left[\mathrm{SiO}_{4}\right]$ tetrahedron $[20,21]$. The $\alpha^{\prime}{ }_{\mathrm{H}}-\mathrm{C}_{2} \mathrm{~S}$ changes rapidly to $\alpha-\mathrm{C}_{2} \mathrm{~S}$ when heated to $1425^{\circ} \mathrm{C}$, and $\alpha-\mathrm{C}_{2} \mathrm{~S}$ changes to $\alpha^{\prime}{ }_{\mathrm{H}}-\mathrm{C}_{2} \mathrm{~S}$ when cooled to $1421^{\circ} \mathrm{C}$. $\beta-\mathrm{C}_{2} \mathrm{~S}$ changes rapidly to $\alpha^{\prime}{ }_{\mathrm{L}}-\mathrm{C}_{2} \mathrm{~S}$ at $675^{\circ} \mathrm{C}$, and $\alpha^{\prime}-\mathrm{C}_{2} \mathrm{~S}$ changes to $\beta-\mathrm{C}_{2} \mathrm{~S}$ at $670{ }^{\circ} \mathrm{C}$. Therefore, the transition from $\alpha-\mathrm{C}_{2} \mathrm{~S}$ to $\alpha^{\prime}{ }_{\mathrm{H}}-\mathrm{C}_{2} \mathrm{~S}$ and the transition from $\alpha_{\mathrm{L}}^{\prime}-\mathrm{C}_{2} \mathrm{~S}$ to $\beta-\mathrm{C}_{2} \mathrm{~S}$ are accompanied by hysteresis $[22,23]$.

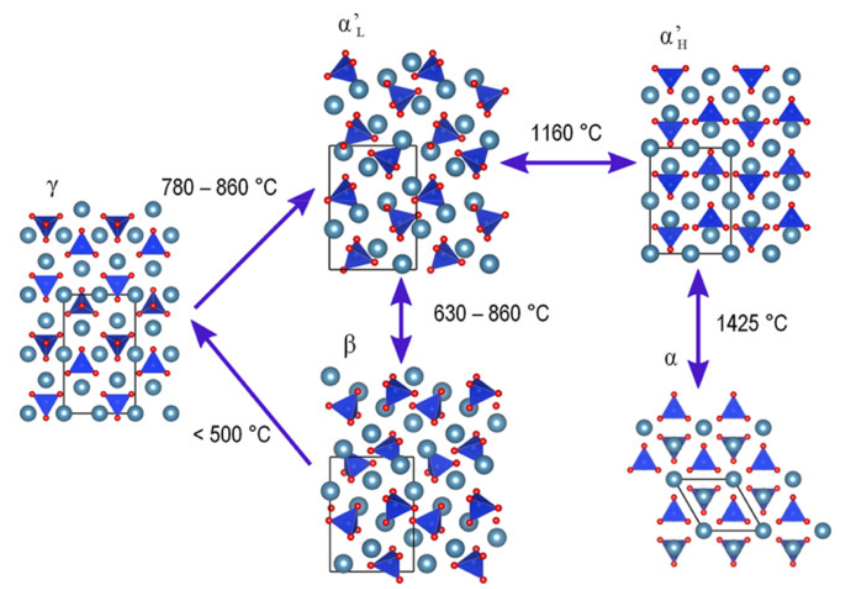

Figure 1. $C_{2} S$ polymorph structures along with the experimental ordering and temperatures of phase transitions [19], adapted from [19], with permission from ACS, 2021. 


\subsection{Hydration Activity}

The order of $C_{2} S$ hydration activity from high to low is $\alpha, \alpha^{\prime}, \beta, \gamma$. That is, the crystal form stabilized by $\mathrm{C}_{2} \mathrm{~S}$ at higher temperatures has higher hydration activity. Usually, $\mathrm{C}_{2} \mathrm{~S}$ in steel slag mostly exists in the form of $\gamma-\mathrm{C}_{2} \mathrm{~S}$ at room temperature, and its $\mathrm{Ca}^{2+}$ coordination number is 6 , while $\mathrm{Ca}^{2+}$ in $\beta-\mathrm{C}_{2} \mathrm{~S}$ has two coordination forms, the coordination numbers are 6 and 8 , and the coordination numbers of $\alpha^{\prime}{ }_{y}-C_{2} S$ and $\alpha-C_{2} S$ are 8 and 10 , respectively. Since the total strength of the bonds around an ion is equal to its formal charge, for oxygen atoms, the total number is two units, one of which is assigned to $\mathrm{Si}$ to form $\mathrm{Si}-\mathrm{O}$ bonds. The other bond strength unit is distributed among $\mathrm{n}$ Ca ions coordinated by $\mathrm{O}$. In $\gamma-\mathrm{C}_{2} \mathrm{~S}, n=3$, the strength of each bond is $1 / 3$. In $\beta-\mathrm{C}_{2} \mathrm{~S}, n=3 / 4$ makes the strength of the $\mathrm{Ca}-\mathrm{O}$ bond smaller than that of form. In addition, the coordination of $\mathrm{Ca}^{2+}$ in the $\beta-\mathrm{C}_{2} \mathrm{~S}$ structure is irregular, which leads to vacancy defects in the lattice. Therefore, $\mathrm{H}$ ions are more likely to break $\mathrm{Ca}-\mathrm{O}$ bonds in $\beta-\mathrm{C}_{2} \mathrm{~S}$ during hydration, and the hydration activity of $\beta-\mathrm{C}_{2} \mathrm{~S}$ is lower than $\beta-\mathrm{C}_{2} \mathrm{~S}$ [24-26].

The hydration mechanism of $\mathrm{C}_{2} \mathrm{~S}$ crystal form is studied by density functional theory (DFT) and molecular dynamics simulation. The constructed Wulff shape of the $\gamma-\mathrm{C}_{2} \mathrm{~S}$ is more symmetric, which reflects the higher symmetry of this polymorph. The water adsorption energies obtained by DFT for $\gamma-\mathrm{C}_{2} \mathrm{~S}$ surfaces are generally higher than those for the $\beta-$ form, and the dissociation process entails lower energy barriers. The $\gamma-C_{2} S$ surfaces are less stable than the $\beta-C_{2} S$ ones in vacuum and the water adsorption and dissociation are energetically favorable. Due to the more symmetrical structure of $\gamma-C_{2} S$, there is a considerably lower number of reactive sites on the $\gamma-C_{2} S$ surface (almost 2.5 times lower) compared with those in $\beta-\mathrm{C}_{2} \mathrm{~S}$. At very short simulation times, water dissociates faster on $\gamma-C_{2} S$, yet the reactions slow as the few reactive sites are saturated. In contrast, $\beta-C_{2} S$ keeps on reacting for a longer time since the surface has more reactive points [27-29].

\subsection{Carbonation Activity}

$\beta-C_{2} S$ and $\gamma-C_{2} S$ have great potential for $\mathrm{CO}_{2}$ capture and sequestration. The carbonation activity of $\beta-C_{2} S$ is derived from the hydration activity of $\beta-C_{2} S$, and its purpose is to obtain higher strength during hydration and hardening of $\beta-C_{2} S$, which will be explained in the following Section 5.1 [30-32].

Although $\gamma-C_{2} S$ has the weakest hydration activity among the five $C_{2} S$ crystal forms, $\gamma-\mathrm{C}_{2} \mathrm{~S}$ has a strong ability to adsorb water [33]. It can absorb more water as a reaction medium and provide a place for carbonation reaction, and its carbonation rate is twice that of $\beta-C_{2} S[34,35]$. Due to the weak water reactivity of $\gamma-C_{2} S$ and the low dissolution rate of $\mathrm{Ca}^{2+}$ and $\mathrm{OH}^{-}$at room temperature, unlike the carbonation reaction of $\beta-\mathrm{C}_{2} \mathrm{~S}, \gamma-\mathrm{C}_{2} \mathrm{~S}$ does not form an intermediate product $\mathrm{Ca}(\mathrm{OH})_{2}$, but directly reacts with carbonic acid to form $\mathrm{CaCO}_{3}$. The reaction formula is as follows [36].

$$
\begin{gathered}
\mathrm{CO}_{2}+\mathrm{H}_{2} \mathrm{O} \rightarrow \mathrm{H}_{2} \mathrm{CO}_{3} \\
2 \mathrm{CaO} \cdot \mathrm{SiO}_{2}+2 \mathrm{H}_{2} \mathrm{CO}_{3} \rightarrow \mathrm{CaCO}_{3}+\mathrm{SiO}_{2}+2 \mathrm{H}_{2} \mathrm{O}
\end{gathered}
$$

The carbonation process of $\gamma-\mathrm{C}_{2} \mathrm{~S}$ is shown in Figure 2. First, $\gamma-\mathrm{C}_{2} \mathrm{~S}$ forms thin films on the surface of the particles, providing a site for $\mathrm{Ca}^{2+}$ dissociation and $\mathrm{CO}_{2}$ dissolution. Then, $\mathrm{CaCO}_{3}$ precipitation and $\mathrm{SiO}_{2}$ are formed, and the $\mathrm{SiO}_{2}$ is transformed into calcium-modified silica gel on the particle surface with the combined action of water and calcium. Finally, as the reaction continues, the calcium-modified silica gel becomes thicker, and the carbonation reaction gradually slows down and finally stops [37].

The crystalline forms of calcium carbonate formed by carbonation of $\beta-\mathrm{C}_{2} \mathrm{~S}$ and $\gamma-\mathrm{C}_{2} \mathrm{~S}$ are also different [38]. The carbonation products of $\beta-\mathrm{C}_{2} \mathrm{~S}$ are calcite and aragonite, while the carbonation products of $\gamma-\mathrm{C}_{2} \mathrm{~S}$ are mainly vaterite. The carbonation process of $\beta-C_{2} S$ is actually the reaction of hydration products with carbon dioxide, and the crystal form of calcium carbonate has little relationship with the structure of $\beta-C_{2} S$; however, the 
distribution of $\mathrm{Ca}$ in the crystal structure of vaterite is similar to that of $\gamma-\mathrm{C}_{2} \mathrm{~S}$, so vaterite is the main product of $\gamma-\mathrm{C}_{2} \mathrm{~S}$ carbonation $[39,40]$.
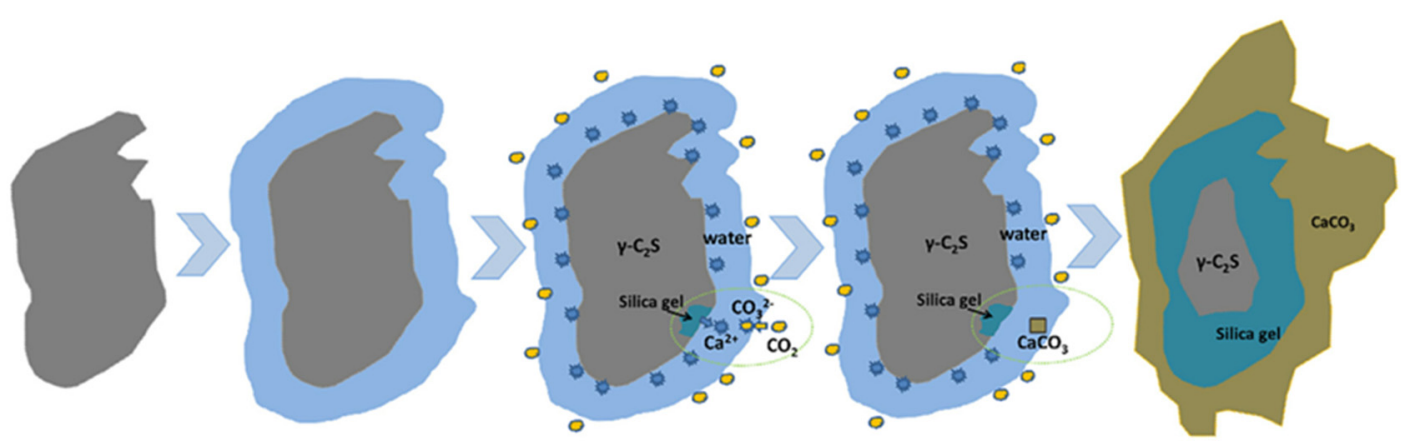

Figure 2. A conceptual carbonation model diagram of the $\gamma-\mathrm{C}_{2} \mathrm{~S}$ particle [37], adapted from [37], with permission from Elsevier, 2021.

\section{Precipitation Process of Dicalcium Silicate in Steel Slag}

The precipitation process of $\mathrm{C}_{2} \mathrm{~S}$ in steel slag can be calculated and simulated by thermodynamic software FactSage. Under the condition of gas-slag equilibrium $\left(\mathrm{P}_{\mathrm{O}_{2}}=0.21 \mathrm{~atm}\right)$, the precipitation of each phase of steel slag changes with temperature. As shown in Figure 3, the $\mathrm{C}_{2} \mathrm{~S}\left(\mathrm{Ca}_{2} \mathrm{SiO}_{4}\right)$ phase begins to decompose from the $\mathrm{C}_{3} \mathrm{~S}\left(\mathrm{Ca}_{3} \mathrm{SiO}_{5}\right)$ phase at $1420{ }^{\circ} \mathrm{C}$. As the temperature decreases to $1300{ }^{\circ} \mathrm{C}$, the $\mathrm{C}_{3} \mathrm{~S}$ phase completely decomposes and a large number of $\mathrm{C}_{2} \mathrm{~S}$ phases precipitate near this temperature. At $1190^{\circ} \mathrm{C}$, the precipitation amount of the $\mathrm{C}_{2} \mathrm{~S}$ phase and $\mathrm{C}_{2} \mathrm{~F}\left(\mathrm{Ca}_{2} \mathrm{Fe}_{2} \mathrm{O}_{5}\right)$ phase reaches the maximum, and the liquidus drops to 0 . The final phase is mainly the $\mathrm{C}_{2} \mathrm{~S}$ phase and $\mathrm{C}_{2} \mathrm{~F}$ phase, accompanied by some $\mathrm{f}-\mathrm{CaO}$ and $\mathrm{f}-\mathrm{MgO}$ [41].

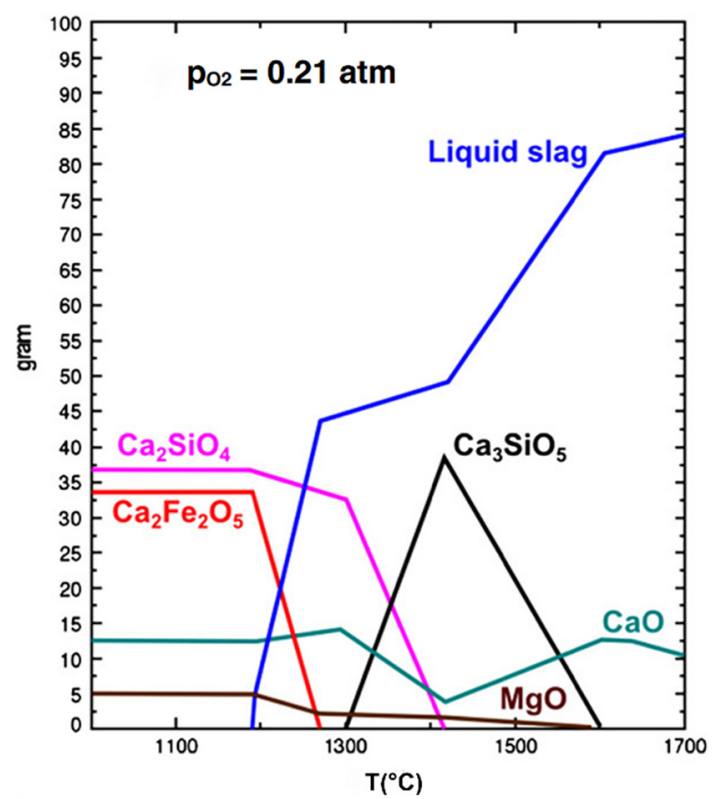

Figure 3. Steel slag phase content changes with temperature [41], adapted from [41], with permission from Elsevier, 2021.

The precipitation process of the $\mathrm{C}_{2} \mathrm{~S}$ phase in steel slag is affected by cooling mode and other components in steel slag, but FactSage software cannot calculate it. The cooling rate will not affect the composition of the steel slag ore phase but will affect the particle size and morphology of the ore phase. By adjusting the cooling rate and constant temperature time at a specific temperature, the content of the ore phase and grain size can be affected [42]. Rapid cooling is easy to form the glass phase, and the grain size of its mineral phase is smaller $(10 \sim 50 \mu \mathrm{m})$ and its composition more uniform. Slow cooling is beneficial to the 
crystallization of silicate minerals, and the grain size can grow to $300 \mu \mathrm{m}[10,26,43]$. When steel slag contains a certain amount of $\mathrm{Cr}, \mathrm{Cr}^{2+}$ will replace $\mathrm{Ca}^{2+}$ and enter its crystal when dicalcium silicate undergoes crystal transformation [44]; P will cause obvious phase segregation in steel slag and form $\mathrm{C}_{2} \mathrm{~S}-\mathrm{C}_{3} \mathrm{P}$ solid solution [45]; when the steel slag contains a certain amount of $\mathrm{CaF}_{2}, \mathrm{CaF}_{2}$ reacts with $\mathrm{CaO}$ and $\mathrm{SiO}_{2}$ to form gun spar $\left(\mathrm{Ca}_{4} \mathrm{Si}_{2} \mathrm{O}_{7} \mathrm{~F}_{2}\right)$. As an early-formed mineral, gun spar will inhibit the formation of $\mathrm{Ca}_{2} \mathrm{SiO}_{4}[46,47]$.

\section{Hydration Characteristics of Dicalcium Silicate in Steel Slag}

\subsection{Application Status}

As mention earlier, $\mathrm{C}_{2} \mathrm{~S}$ has a certain hydration activity. It is one of the main ore phases of steel slag (BOF, AOD, and EAF slag, etc.) [48], and the main chemical composition of steel slag ( $\mathrm{CaO} 45-60 \%, \mathrm{SiO}_{2} 10-15 \%$, FeO 7-20\%, $\mathrm{Fe}_{2} \mathrm{O}_{3} 3-9 \%, \mathrm{MgO} 3-13 \%, \mathrm{Al}_{2} \mathrm{O}_{3} 1-5 \%$, and $\mathrm{P}_{2} \mathrm{O}_{5} 1-4 \%$ [49]), and mineral phase composition (dicalcium silicate $\left(2 \mathrm{CaO} \cdot \mathrm{SiO}_{2}, \mathrm{C}_{2} \mathrm{~S}\right.$ ), tricalcium silicate $\left(3 \mathrm{CaO} \cdot \mathrm{SiO}_{2}, \mathrm{C}_{3} \mathrm{~S}\right)$, dicalcium ferrite $\left(2 \mathrm{CaO} \cdot \mathrm{Fe}_{2} \mathrm{O}_{3}, \mathrm{C} 2 \mathrm{~F}\right)$ and $\mathrm{RO}$ phase ( $\mathrm{CaO}-\mathrm{FeO}-\mathrm{MnO}-\mathrm{MgO}$ solid solution), tetracalcium ferroaluminate $\left(4 \mathrm{CaO} \cdot \mathrm{Al}_{2} \mathrm{O}_{3} \cdot \mathrm{Fe}_{2} \mathrm{O}_{3}\right.$, $\left.\mathrm{C}_{4} \mathrm{AF}\right)$, olivine $\left(\mathrm{MgSiO}_{4} \cdot \mathrm{FeSiO}_{4}\right)$, merwinite $\left(\mathrm{MgO} \cdot 2 \mathrm{SiO}_{2} \cdot 3 \mathrm{CaO}\right)$, free magnesium oxide $(\mathrm{f}-\mathrm{MgO})$, and free calcium oxide $(\mathrm{f}-\mathrm{CaO})[50,51])$ are similar to cement clinker [52]. It has been proved that it is feasible and effective in terms of resources, energy-saving, emission reduction, and economic benefits in the cement industry $[53,54]$.

The hydration activity of steel slag originates from $C_{2} S$ and $C_{3} S$ in the slag, of which $\mathrm{C}_{3} \mathrm{~S}$ activity is stronger than $\mathrm{C}_{2} \mathrm{~S}$ and generally occurs in steel slag with basicity greater than 2.4. However, when the steel slag contains excessive $\mathrm{P}_{2} \mathrm{O}_{5}$, the formation of $\mathrm{C}_{3} \mathrm{~S}$ will be prevented, and $\mathrm{C}_{3} \mathrm{~S}$ will be decomposed [55]. Therefore, $\mathrm{C}_{2} \mathrm{~S}$ plays a decisive role in the hydration strength of steel slag [56]. Compared with industrial cement, the formation temperature of steel slag is about $1650{ }^{\circ} \mathrm{C}$, but Portland cement clinker is fired at $1460{ }^{\circ} \mathrm{C}$, so steel slag is called "overburned Portland cement clinker". Steel slag is regarded as overburned Portland cement clinker, which can be used as auxiliary cementing material to improve the activity of cement. However, $\mathrm{C}_{2} \mathrm{~S}$ minerals in steel slag have dense crystals, coarse and complete crystals, and slow hydration speed [57]. The $C_{2} S$ hydration reaction formula is as follows:

$$
\begin{gathered}
2 \mathrm{CaO} \cdot \mathrm{SiO}_{2}+\mathrm{nH}_{2} \mathrm{O} \rightarrow \mathrm{CaO} \cdot \mathrm{SiO}_{2} \cdot(\mathrm{n}-1) \mathrm{H}_{2} \mathrm{O}+\mathrm{Ca}(\mathrm{OH})_{2} \\
2 \mathrm{CaO} \cdot \mathrm{SiO}_{2}+\mathrm{nH}_{2} \mathrm{O} \rightarrow 2 \mathrm{CaO} \cdot \mathrm{SiO}_{2} \cdot \mathrm{nH}_{2} \mathrm{O}
\end{gathered}
$$

The hydration characteristics of $\mathrm{C}_{2} \mathrm{~S}$ in steel slag are as follows: (i) XRD (X-ray diffraction analysis) before and after hydration as shown in Figure 4; the hydration products mainly consist of $\mathrm{C}-\mathrm{S}-\mathrm{H}$ gel, $\mathrm{Ca}(\mathrm{OH})_{2}$, and some unhydrated $\mathrm{C}_{2} \mathrm{~S}$; (ii) the interface between $\mathrm{C}-\mathrm{S}-\mathrm{H}$ gel generated by $\mathrm{C}_{2} \mathrm{~S}$ hydration and $\mathrm{RO}$ phase particles is the weak link of the hydration system. The $\mathrm{C}-\mathrm{S}-\mathrm{H}$ gel generated by hydration is not firmly bonded to each other, and cracks are easily formed [58,59].

A small amount of steel slag will not have a negative impact on the quality of cement produced, but the excessive amount of steel slag will inhibit the early hydration of cement [60]. For GGFBS (ground granulated blast furnace slag) concrete, the hydraulic strength of concrete with GGFBS content less than $50 \%$ begins to increase at 7 days, the compressive strength at 28 days is basically the same as that of ordinary concrete, and the compressive strength at 56 days is higher than that of ordinary concrete [61].

Tsakiridis et al. [62] investigated the possibility of adding $10.5 \%$ steel slag to raw meal for the production of Portland cement clinker, sintered at $1450{ }^{\circ} \mathrm{C}$, and used ordinary Portland cement material as the reference sample. The addition of $10.5 \%$ steel slag standard concentration and solidification time will have a slight impact on the water content. The hydrated products were examined by XRD analysis on the 2nd, 7th, 28th, and 90th days. The main mineral phases are $C_{3} S, C_{2} S, C_{3} A$, and $C_{4} A F$, which do not affect their mineralogical composition. Zhuang et al. [63] added 30\% steel slag instead of Portland cement. It was found that the addition of steel slag increased the concentration of $\mathrm{Ca}$ in 
pore solution, reduced the supersaturation of pore solution relative to $\mathrm{C}-\mathrm{H}$, inhibited the nucleation and growth of $\mathrm{C}-\mathrm{S}-\mathrm{H}$, and blocked the initial setting of cement slurry.

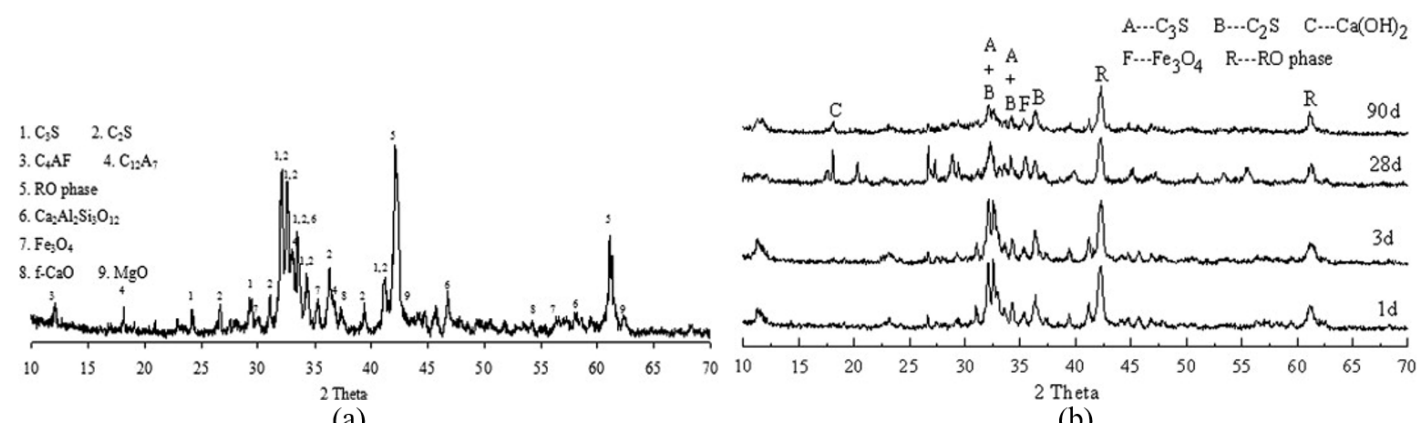

(a)

(b)

Figure 4. XRD patterns of original steel slag and hydration products of steel slag. (a) Original; (b) after hydration [59], adapted from [59], with permission from Elsevier, 2021.

The compressive strength of $100 \%$ Steel slag concrete is much lower than that of $100 \%$ GGFBS concrete at any age, which indicates that the contribution of steel slag to the compressive strength of concrete is much smaller than that of GGFBS. However, it is of interest to note that for the late compressive strength of concrete, the performance of the composite mineral admixture with $80 \%$ GGFBS and $20 \%$ steel slag is better than that of pure GGFBS [64]. This result may be attributed to the indirect contribution of steel slag to strength: It promotes the hydration of cement and reaction of GGFBS by improving the hydration condition because its reaction needs much less water than the cement hydration and its unreacted particles can act as a nucleation agent [65]. The current research results show that the best mixing rate of steel slag is about $10 \sim 20 \%$ in order to achieve the same performance as ordinary Portland cement $[66,67]$.

\subsection{Hydration Activity Activation}

$\gamma-\mathrm{C}_{2} \mathrm{~S}$ exists stably at ambient temperature, and the main form of dicalcium silicate phase in steel slag is often $\gamma-C_{2} S$ with the weakest hydration activity [11]. At present, studies have proved that mechanical activation, high - temperature activation, chemical activation, and carbonation activation can improve the hydration activity of $\gamma-\mathrm{C}_{2} \mathrm{~S}$ in steel slag [2].

\subsubsection{Mechanical Activation}

Mechanical activation is the most basic and popular activation method, which mainly improves the fineness of steel slag through physical grinding [68]. Physical grinding can cause dislocations and defects in $\mathrm{C}_{2} \mathrm{~S}$ mineral phase grains, as well as recrystallization on the grain surface or the formation of a water-soluble amorphous structure; the amount of heat released per surface area increased with milling time $[68,69]$. The reason is that with the particle size decreases, the specific surface area of steel slag increases, and the contact area between $\mathrm{C}_{2} \mathrm{~S}$ and water in steel slag increases, the hydration rate of steel slag is stimulated [69-73]. With the increase of surface area, the reaction ability is enhanced and the reaction speed is accelerated. The more thorough the reaction, the higher the strength of mortar. At the same time, the fine slag particles without hydration reaction are uniformly dispersed in the pores, and the gel fills the pores and cracks, which improves the pore structure and improves the compactness of the cementitious material. In addition, the skeleton of micro-aggregate, fine mineral powder particles make the cementitious material have better particle size distribution and forms a self-compact packing system with compact filling structure and fine mesoscopic layer, which further optimizes the gel structure, improves the interfacial bonding performance between aggregates and the microstructure of mortar, and thus improves the macroscopic performance of mortar [74,75]. 
Mechanical grinding has proved to play a positive role in hydration activity of blast furnace slag; there is almost a linear relationship between hydration activity index and specific surface area at different ages. The compressive strength of the benchmark mortar at the same age increases with the increase of the specific surface area of GGFBS. The reason is that with the increase of the specific surface area of GGFBS, the proportion of fine particles in GGFBS increases, and the void filling of cement particles is more uniform and effective [76]. Ultrafine steel slag shows high early activity. When the particle size $\mathrm{D}_{50}$ of steel slag powder reaches $8.11 \mu \mathrm{m}, 5.10 \mu \mathrm{m}$, and $2.52 \mu \mathrm{m}$, respectively, the activity index is as high as $82 \%, 87 \%$, and $95 \%$ after 28 days of hydration, which all meet the requirement of $80 \%$ in Chinese national standard GB/T20491-2006. By contrast, the activity index of ordinary steel slag powder $\left(\mathrm{D}_{50}=13.30 \mu \mathrm{m}\right)$ is only $78 \%$ [77]. Wang et al. [78] also confirmed that ultrafine steel slag has high early activity, but its comprehensive activity is still far lower than that of cement. Due to the high content of iron in steel slag, the cost and energy consumption of fine grinding steel slag are high, and the effect of improving $\mathrm{C}_{2} \mathrm{~S}$ activity in steel slag only by mechanical activation is not ideal [79].

\subsubsection{High Temperature Activation}

Affected by the thermal stress, the network structure $\mathrm{Si}-\mathrm{O}$ bond of $\mathrm{C}_{2} \mathrm{~S}$ in steel slag is more likely to break, thus resulting in high-temperature activation [80], promoting the depolymerization of silicate network structure, and thus improving its hydration reaction rate. There are mainly two ways to excite steel slag at high temperature: One is to increase the hydration temperature of steel slag by autoclave or steam curing; the other one is that when steel slag is applied to concrete, the activity of steel slag is excited by the temperature rise formed by hydration and heat release of cementitious materials.

It is feasible to adopt two high-temperature activation methods at the same time. Yan et al. [81] used $55 \%$ cement $+45 \%$ steel slag (water-binder ratio 0.42 ) to cure at $20^{\circ} \mathrm{C}$ and $65{ }^{\circ} \mathrm{C}$ for 3 days, respectively, and compared with $100 \%$ cement; it was found that high-temperature curing can obviously shorten its hydration induction period and accelerate its early reaction rate, but has little effect on the types of hydration products. Feng et al. [82] found that the porosity of steel slag solidified at $20^{\circ} \mathrm{C}$ and $60^{\circ} \mathrm{C}$ was $18.851 \%$ and $24.207 \%$, respectively. Compared with the sample at $20^{\circ} \mathrm{C}$, the sample at $60{ }^{\circ} \mathrm{C}$ has higher porosity, and the volume of harmful pores (50-200 nm) and micro-harmful pores $(20-50 \mathrm{~nm})$ of the sample cured at $60^{\circ} \mathrm{C}$ is larger. This finding is similar to the experimental results of Shirani et al. [83]. The critical pore entry sizes of Polante cement at $20^{\circ} \mathrm{C}, 40^{\circ} \mathrm{C}$, and $60{ }^{\circ} \mathrm{C}$ are mainly $27 \mathrm{~nm}, 22 \mathrm{~nm}$, and $23 \mathrm{~nm}$. Increasing the hydration temperature can improve the early hydration rate and early strength of $C_{2} S$ in steel slag to a certain extent [51], but due to the low comprehensive activity of steel slag, rapid early hydration easily causes macropores or cracks and even inhibits late hydration and reduces the final strength [84].

\subsubsection{Chemical Activation}

The principle of chemical activation of steel slag activity is that the Si-O bond in the $\left[\mathrm{SiO}_{4}\right]$ tetrahedron in dicalcium silicate will break during the grinding process of steel slag. In the alkaline environment formed by the activator, the $\left[\mathrm{SiO}_{4}\right]$ tetrahedron will depolymerize and then generate $\mathrm{H}_{3} \mathrm{SiO}_{4}{ }^{-}$, and $\mathrm{H}_{3} \mathrm{SiO}_{4}{ }^{-}$will react with $\mathrm{Ca}^{2+}$ and $\mathrm{Na}^{+}$plasma and generate zeolite hydration products. The formation of zeolite hydration products consumes $\mathrm{H}_{3} \mathrm{SiO}_{4}{ }^{-}$generated by depolymerization, resulting in continuous destruction of $\mathrm{Si}-\mathrm{O}$ bonds and depolymerization in the end, as shown in Figure 5. Therefore, the mechanism of chemical activation is to introduce chemical components to create an alkaline environment in which dicalcium silicate in steel slag is fully depolymerized and hydrated [2]. Chemical activation can accelerate the hydration of $\mathrm{C}_{2} \mathrm{~S}$ and $\mathrm{C}_{3} \mathrm{~S}$ in steel slag by increasing the number of crystal nuclei and the alkalinity of the liquid phase [85]. With the influence of the activator, steel slag can show higher cementitious performance, and the alkalinity of the liquid phase can also improve the early hydration of active components of 
steel slag, but the hydration degree of inert components (dicalcium ferrite, RO equal) in steel slag is still low even under higher alkalinity conditions [86].

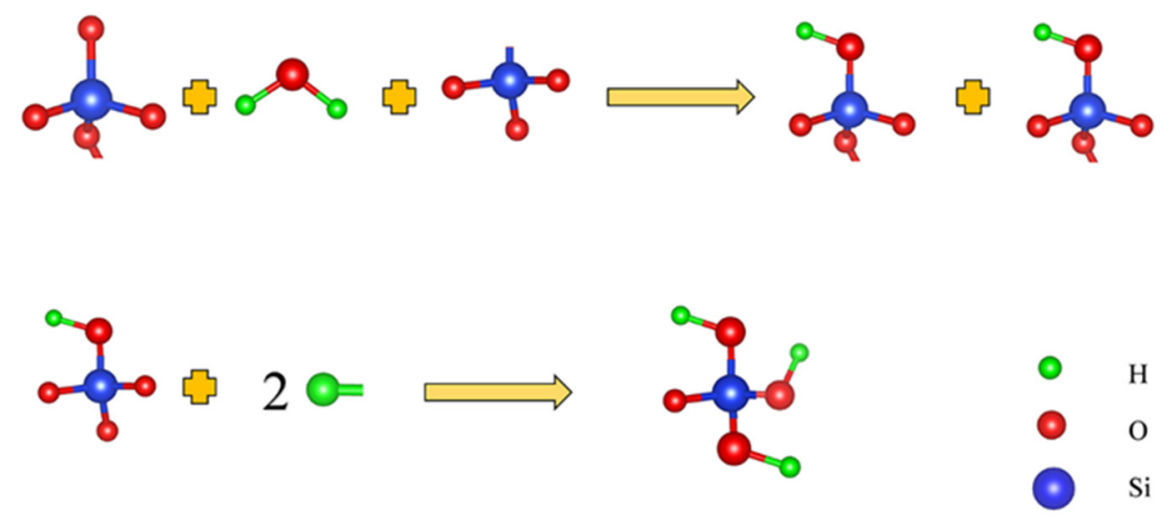

Figure 5. Schematic diagram of $\left[\mathrm{SiO}_{4}\right]$ tetrahedron depolymerization to generate $\mathrm{H}_{3} \mathrm{SiO}_{4}{ }^{-}$.

Different alkaline solutions have different activation effects on the hydration activity of $\gamma-\mathrm{C}_{2} \mathrm{~S}$. Warda Ashraf [87] compared the effects of $\mathrm{Na}_{2} \mathrm{CO}_{3}, \mathrm{NaHCO}_{3}, \mathrm{Na}_{2} \mathrm{SiO}_{3}$, and $\mathrm{NaOH}$ activators on the hydration reaction of $\gamma-\mathrm{C}_{2} \mathrm{~S}$ and tested their hydration exotherm. The results are shown in Figure 6, the total heat release of the $\mathrm{NaOH}$ activator solution is so much less that it is negligible, while the $\mathrm{Na}_{2} \mathrm{CO}_{3}, \mathrm{NaHCO}_{3}$, and $\mathrm{Na}_{2} \mathrm{SiO}_{3}$ curves show an increase in the total heat release over the measurement duration, with $\mathrm{NaHCO}_{3}$-activated $\gamma-\mathrm{C}_{2} \mathrm{~S}$ having the largest heat release, far exceeding the other three activators. The main product of $\gamma-\mathrm{C}_{2} \mathrm{~S}$ hydration reaction after activation is $\mathrm{C}-(\mathrm{N})-\mathrm{S}-\mathrm{H}$ with plate shape, which is similar to the $\mathrm{C}-\mathrm{S}-\mathrm{H}$ structure. Using sodium silicate and sodium hydroxide as the mixed activator, Liu et al. [88] studied the early evolution of alkali-activated steel slag at $60^{\circ} \mathrm{C}$. The results show that the $\mathrm{C}_{2} \mathrm{~S}$ phase in the steel slag appears as an amorphous phase and zeolite-like phase after dissolution in the activator. With the increase of the curing time of the alkali-activated steel slag, the activated $\mathrm{SiO}_{2}$ and $\mathrm{Al}_{2} \mathrm{O}_{3}$ are dissolved, and the surface of the raw material particles becomes rough. The content of $\mathrm{Ca}(\mathrm{OH})_{2}$ in the hydration products of activated steel slag is low and the crystallinity is poor. More microcracks and unhydrated particles can be seen in alkali-activated steel slag slurry, which destroys the development of strength, and the compressive strength is only $30-40 \%$ of the strength of cement slurry [89]. The main reason for this phenomenon is that although early high temperature curing can promote the early hydration of slag and increase the hydration products, the permeability of steel slag will be reduced due to the increase of temperature and the short dormancy period of hydration heat excited by alkali, the increase of pores and micro-cracks, and the coarsening of microstructure [90].
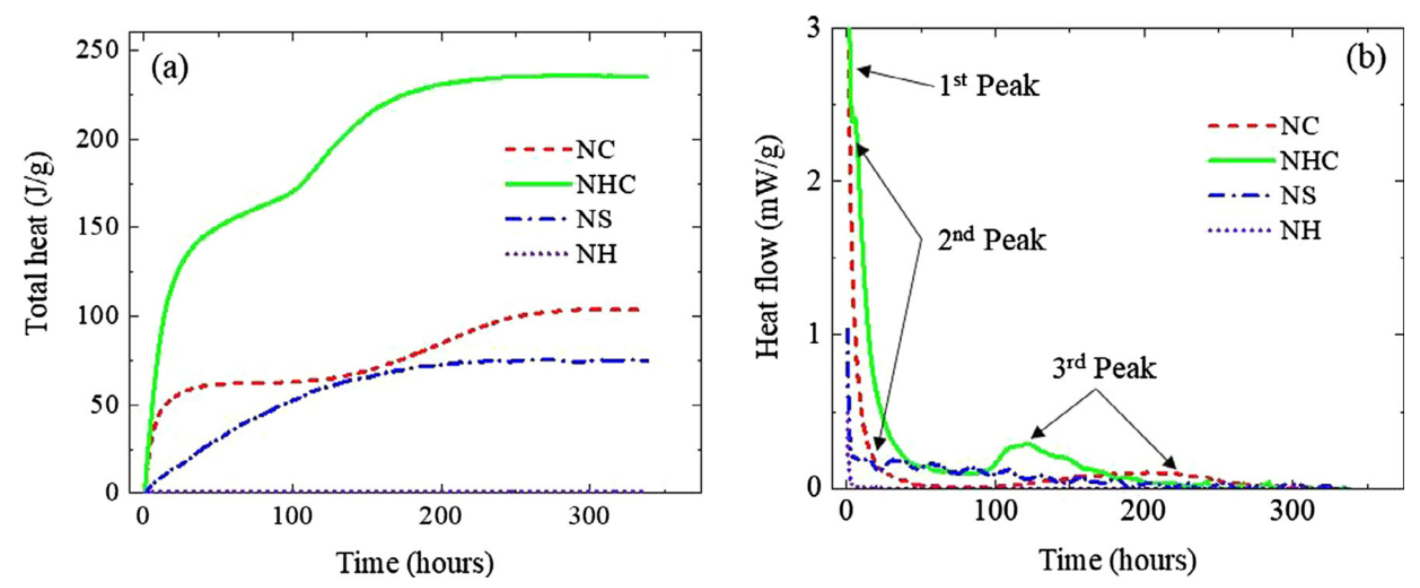

Figure 6. (a) Total heat released and (b) heat flow graphs for chemically activated $\gamma-C_{2} S$ systems [87], adapted from [87], with permission from Elsevier, 2021. 
Physics, high temperature, and chemistry can stimulate the activity of the $C_{2} S$ phase in steel slag. However, it still cannot change the fact that the content of active components in steel slag is not high. In addition, due to the unstable composition, poor grinding property, and poor volume stability of steel slag, its application in cement production is greatly limited [91-94]. Therefore, in order to fundamentally solve the problem of comprehensive utilization of steel slag, it is necessary to increase the content of active components in steel slag, thereby increasing the proportion of steel slag mixed in cement and exploring the relationship between the performance of the final clinker and the best process [95].

\section{Carbonation Characteristics of Dicalcium Silicate in Steel Slag}

\subsection{Cement Modification}

Carbonation reaction can promote the hydration of $\beta-\mathrm{C}_{2} \mathrm{~S}$, and $\mathrm{Ca}(\mathrm{OH})_{2}$ generated by hydration of $\beta-\mathrm{C}_{2} \mathrm{~S}$ dissolves with $\mathrm{CO}_{2}$ in water to form $\mathrm{CO}_{3}{ }^{2+}$ and reacts to form $\mathrm{CaCO}_{3}$. The formed $\mathrm{C}-\mathrm{S}-\mathrm{H}$ gel is gradually decalcified with the action of $\mathrm{CO}_{2}$ and finally converted into $\mathrm{S}-\mathrm{H}$ and $\mathrm{CaCO}_{3}$. The consumption of the product promotes the positive progress of $\mathrm{C}_{2} \mathrm{~S}$ hydration reaction Formulas (3) and (4), thus accelerating the overall hydration reaction rate of steel slag. $\gamma-\mathrm{C}_{2} \mathrm{~S}$ can also react directly with carbonate to produce $\mathrm{CaCO}_{3}$, and the formed $\mathrm{CaCO}_{3}$ can improve the compressive strength of cement [96-100]. Compared with ordinary Portland cement concrete, concrete mixed with auxiliary cementitious materials such as fly ash (FA) or blast furnace slag (BFS) is more prone to carbonation [101]. The latest research shows that with the increase of $\gamma-\mathrm{C}_{2} \mathrm{~S}$ and GGBFS content in cement, the carbonation rate increases, and more calcium carbonate is formed in pores, which reduces porosity and improves its overall strength [102-104].

Mo et al. [105] studied the effect of $\mathrm{CO}_{2}$ curing conditions on the microstructure and mechanical strength of $100 \%$ steel slag slurry- $80 \%$ steel slag and $20 \%$ cement slurry. The results show that around $34.3 \% \mathrm{CaCO}_{3}$ was formed in the $100 \%$ steel slag after 14 days of $\mathrm{CO}_{2}$ curing. This led to a shift of pore diameter from 0.3 to $3 \mu \mathrm{m}$ in the paste before carbonation to smaller than $0.1 \mu \mathrm{m}$ in the carbonated paste, and hence generating a compressive strength of up to $44.1 \mathrm{MPa}$, which was approximately 13 times higher than that of the pastes before $\mathrm{CO}_{2}$ curing. This is because the formation of $\mathrm{CaCO}_{3}$ densifies the microstructure of steel slag slurry, reduces the pore size and total porosity, and then improves the compressive strength of steel slag slurry. The main factors affecting the carbonation rate of steel slag slurry are: diffusion of $\mathrm{CO}_{2}$ in slurry voids and leaching diffusion of $\mathrm{Ca}^{2+}$; the addition of $20 \%$ cement significantly improves its compressive strength. Carbonation of steel slag consumes free- $\mathrm{CaO}$ and free- $\mathrm{MgO}$, improving the volume stability of steel slag in cement production. Moreover, the carbonized product $\left(\mathrm{CaCO}_{3}\right)$ provides a nucleation site for $\mathrm{C}_{2} \mathrm{~S}$ hydration, which can improve the mechanical properties of cementitious materials [81,106,107]. Although the carbonation of steel slag can promote the hydration of $\mathrm{C}_{2} \mathrm{~S}$, many factors such as incomplete carbonation, weak carbonation activity of RO phase ( $\mathrm{MgO}$ solid solution in $\mathrm{RO}$ phase can only carbonize 58.6\% [106]), almost no carbonation reactivity of the iron-containing phase, and multiple requirements for carbonation curing process conditions, cannot be solved.

\subsection{Sequestration of Carbon Dioxide}

The $\mathrm{C}_{2} \mathrm{~S}$ phase endows the steel slag with the ability to capture carbon dioxide in the form of thermodynamic product calcium carbonate [107], and the $C_{2} S$ in the steel slag is mostly $\gamma-\mathrm{C}_{2} \mathrm{~S}$, so the steel slag has a high carbon dioxide sequestration capacity, and, theoretically, the maximum carbon sequestration potential is $159.4 \mathrm{gCO}_{2} \cdot \mathrm{kg}_{\text {slag }}{ }^{-1}$ [108]. However, the real absorption capacity depends on carbonation conditions, and the maximum absorption can reach $75 \%$ of the theoretical volume [109]. Therefore, fixing carbon dioxide by carbonation of $\gamma-\mathrm{C}_{2} \mathrm{~S}$ in steel slag can not only effectively reduce the greenhouse effect, but also promote the utilization of solid waste of steel slag, which has a positive impact on environmental protection. Both the direct and indirect carbonation of steel slag can effectively utilize steel slag [110]; carbonized steel slag will be more stable 
and will not easily release microelements [111,112]. The carbonized products can be reused in the construction industry with positive effects.

Conventional storage of carbon dioxide by steel slag includes direct carbonation, accelerated carbonation, and carbon dioxide aqueous solution. At present, there have been a large number of research reports concerning that issue, among which carbon dioxide aqueous solution has the best effect. The carbonation process of steel slag in carbon dioxide aqueous solution includes $\mathrm{Ca}^{2+}$ leaching, $\mathrm{CO}_{2}$ dissolution, and $\mathrm{CaCO}_{3}$ precipitation [113]. According to the thermodynamic software HSC, the carbonation reaction equation of steel slag is simulated and calculated, and $\Delta \mathrm{G}<0$ when the reaction is below $700 \mathrm{~K}$ which indicates that the carbonation reaction of steel slag is a spontaneous process [114].

The direct carbonation efficiency of steel slag is low. Yu et al. [115] used BOF and EAF slag for carbonation at high temperatures. The results show that the reaction temperature and carbon dioxide concentration jointly affect the carbonation degree of steel slag. As shown in Figure 7, the higher the temperature is, the more $\mathrm{Ca}$ is consumed. However, at a certain $\mathrm{CO}_{2}$ concentration, the Ca consumption at $550{ }^{\circ} \mathrm{C}$ will be lower than that at $500{ }^{\circ} \mathrm{C}$. The main reason for this abnormal phenomenon is the complex composition of steel slag and reaction surface area. At high temperatures, high $\mathrm{Ca}$ consumption will occur when $\mathrm{CO}_{2}$ concentration is lower than $10 \%$ or $\mathrm{CO}_{2}$ concentration is higher than $75 \%$.
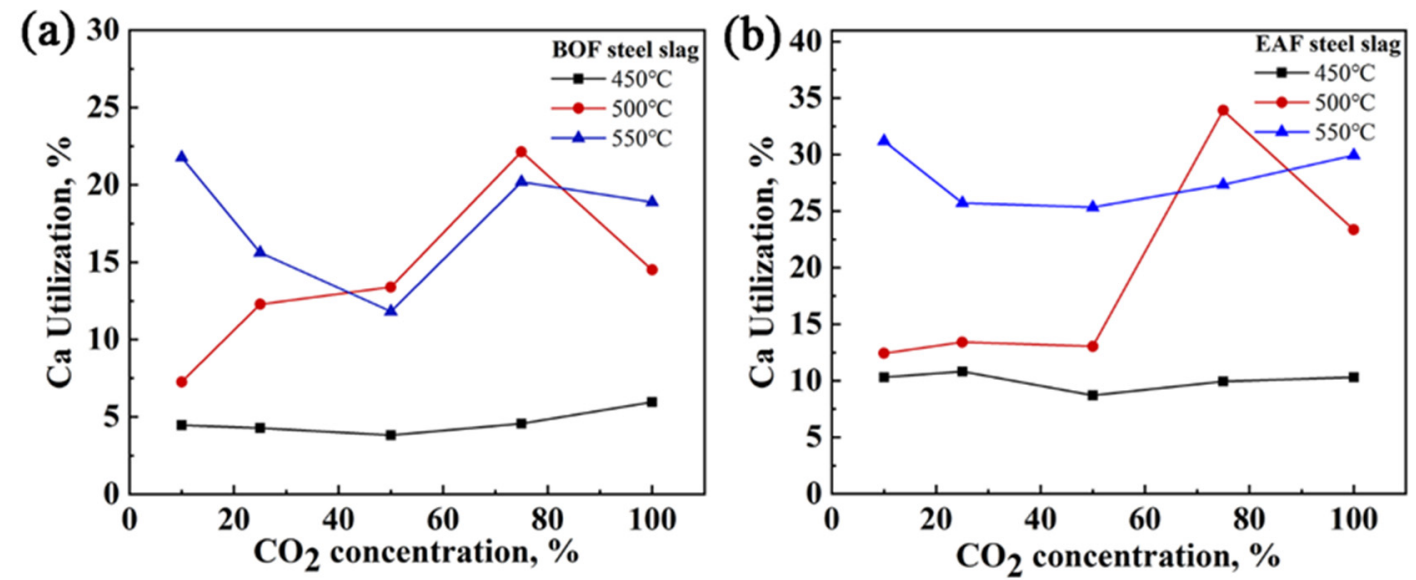

Figure 7. Variation of $\mathrm{Ca}$ utilization with the $\mathrm{CO}_{2}$ concentration for BOF steel slag and EAF steel slag. (a) BOF slag; (b) EAF slag [115], adapted from [115], with permission from ACS, 2021.

Carbon dioxide aqueous solution can effectively improve the carbonation efficiency of steel slag. Huijgen et al. [116,117] dissolved steel slag into the solution to retain carbon dioxide in a high temperature and high-pressure reaction kettle, and systematically changed the process variables (particle size, temperature, carbon dioxide pressure, and reaction time). It was found that the main factors affecting the carbonation reaction rate of steel slag solution were the particle size $(38 \mu \mathrm{m} \sim 2 \mathrm{~mm})$ and reaction temperature $\left(25 \sim 225^{\circ} \mathrm{C}\right)$ of steel slag. Under the condition of 19 bar $\mathrm{CO}_{2}$ pressure, $100{ }^{\circ} \mathrm{C}$, and particle size less than $38 \mu \mathrm{m}$, the maximum carbonation degree of steel slag in $30 \mathrm{~min}$ reaches $74 \%$ of the total Ca content of steel slag. Wang et al. [118] studied the effect of the carbonation rate of AOD slag on chromium's leaching rate from slag. The experimental results show that the maximum carbonation rate of AOD slag is $50 \sim 52 \%\left(\mathrm{~L} / \mathrm{S}=0.4 \mathrm{~mL} / \mathrm{g}, \mathrm{P}_{\mathrm{CO}_{2}}=7.5 \mathrm{bar}\right.$, $\mathrm{t}>6 \mathrm{~h})$, but the chromium leaching rate of $52 \%$ carbonated AOD slag $(7.9 \mathrm{mg} / \mathrm{kg})$ is higher than that of the original AOD slag $(6 \mathrm{mg} / \mathrm{kg}) ; 23 \%$ carbonated AOD slag has the lowest chromium leaching rate $(1.7 \mathrm{mg} / \mathrm{kg})$.

In addition to the carbonation of carbon dioxide aqueous solution, it is feasible to add extractant to the solution to extract $\mathrm{Ca}^{2+}$ from steel slag and then $\mathrm{Ca}^{2+}$ reacts with $\mathrm{CO}_{3}^{2-}$ produced by the $\mathrm{CO}_{2}$. At present, $\mathrm{HCl}, \mathrm{HNO}_{3}, \mathrm{CH}_{3} \mathrm{COOH}$, and ammonium salt are commonly used as extractants. Jo et al. [119] used hydrochloric acid ( $\mathrm{HCl})$ and sodium hydroxide $(\mathrm{NaOH})$ to prepare high purity nano- $\mathrm{CaCO}_{3}$ from steel slag. After the im- 
purities such as iron, aluminum, and magnesium were completely removed from the purified $\mathrm{Ca}(\mathrm{OH})_{2}$, nano- $\mathrm{CaCO}_{3}$ with the particle size of $80 \sim 120 \mathrm{~nm}$ and purity of $98.5 \%$ was prepared by carbonation with $\mathrm{CO}_{2}$. An experiment by Eloneva et al. [120] studied the method of dissolving calcium ions from the converter's steel slag with $\mathrm{CH}_{3} \mathrm{COOH}$ as the solvent and introducing $\mathrm{CO}_{2}$ into the solution to precipitate pure calcium carbonate. It is found that the conversion rate of calcium from solution to precipitation is as high as $86 \%$, and the purity of precipitation is $99.5 \% \sim 99.8 \%$. Calcium carbonate particles produced at low temperature $\left(30^{\circ} \mathrm{C}\right)$ have rhombic particle shape, extremely high brightness $(98.7 \%)$, and small particle size (average $0.6 \mu \mathrm{m}$ ).

There are numerous studies on the carbonation conditions and carbonation ability of steel slag for carbon dioxide sequestration. The essence of carbon dioxide sequestration by steel slag is the process of transforming dicalcium silicate into calcium carbonate.

Aiming at the carbon dioxide absorbent derived from steel slag, many factors should be taken into account. On one hand, the evaluation of steel slag should be conducted. On the other hand, the cost including the transportation cost, the treatment cost and so on should be considered. For example, according to the electrolysis potential of $1.5 \mathrm{~V}$, Faraday efficiency of $90 \%$, dissolution efficiency, and precipitation efficiency of $73 \%$, the energy consumption for producing $1 \mathrm{t} / \mathrm{h}$ calcium carbonate is estimated to be $1462 \mathrm{kWh}$ [119]. Therefore, in future research, with the premise of ensuring carbonation efficiency, more attention should be paid to the experimental cost, so that carbon dioxide sequestration by steel slag becomes a mature, economical, and effective process.

\section{Conclusions}

Due to the hydration activity of the dicalcium silicate phase, steel slag is added in a small amount in cement application without affecting the final performance of cement. Using the carbonation property of dicalcium silicate, steel slag has a strong ability to capture carbon dioxide. This paper put forward the state of the art in steel slag use in Portland cement clinker and Portland cement production. In addition, carbon dioxide sequestration by steel slag used in Portland cement was presented. The conclusions are as follows:

(1) The dicalcium silicate phase in steel slag is easily affected by cooling mode, $\mathrm{FeO}_{z}$, $\mathrm{P}_{2} \mathrm{O}_{5}$, and other components in the precipitation process, forming other types of mineral phases, resulting in a decrease in the content of the dicalcium silicate phase and affecting the comprehensive utilization of steel slag.

(2) For the hydration activity of dicalcium silicate in steel slag, steel slag can provide nucleation sites for the hydration process of steel slag-cement, reduce porosity, and improve the strength of cementitious materials, but excessive steel slag will have a strong inhibition on cement hydration and affect the final quality. Although the dicalcium silicate phase after physical, high-temperature, and chemical activation can improve its early hydration activity to a certain extent, it still cannot change the status quo that there is too much negative influence of the inert phase during its hydration and the overall hydration activity of steel slag is relatively low. Therefore, it is of great significance to further develop the hydration activity of dicalcium silicate in the follow - up research, so as to increase the proportion of steel slag in cement.

(3) For the carbonation characteristics of dicalcium silicate in steel slag, the effect of steel slag size on carbonation efficiency is most significant. The smaller the steel slag size, the larger the total carbonation volume and the higher the $\mathrm{CO}_{2}$ absorption rate. The diffusion barrier in carbonation process is the calcium carbonate layer formed on the shell of steel slag particles, and the thickness of this layer has nothing to do with the size of steel slag particles. The direct carbonation reaction efficiency of steel slag is too low, the indirect carbonation process of carbon dioxide aqueous solution is cumbersome and costly, and the process of steel slag for carbon dioxide sequestration has not been popularized. Therefore, on the basis of existing research, it is necessary to deeply explore the mechanism of the effect of other elements in steel slag on 
the carbonation reaction of dicalcium silicate, in order to optimize the carbonation reaction conditions and increase the carbonation reaction efficiency and rate.

Author Contributions: Conceptualization, X.Z., J.L.; Writing-original draft preparation, H.N.; Review-Research Design, Y.W., Y.Z.; literature search, P.L. All authors have read and agreed to the published version of the manuscript.

Funding: The work was supported by the Natural Science Foundation of Hebei Province (E2020209195) and the Science and Technology Research Project of Hebei Province Colleges and Universities (QN2021116).

Institutional Review Board Statement: Not applicable.

Informed Consent Statement: Not applicable.

Data Availability Statement: No new data were created or analyzed in this study. Data sharing does not apply to this article.

Acknowledgments: The authors give thanks to the anonymous reviewers and all the editors in the process of manuscript revision.

Conflicts of Interest: The authors declare no conflict of interest.

\section{References}

1. Global Crude Steel Output Decreases by 0.9\% in 2020. Available online: https://www.worldsteel.org/media-centre/pressreleases /2021/Global-crude-steel-output-decreases-by-0.9--in-2020.html (accessed on 26 January 2021).

2. Yu, H.M.; Wang, Q. Steel Slag: Treatment and Resource Utilization; Metallurgical Industry Press: Beijing, China, 2015.

3. Meng, H.D.; Liu, L. Stability processing technology and application prospect of steel slag. Steelmaking 2009, 25, 74.

4. Guo, J.; Bao, Y.; Wang, M. Steel slag in China: Treatment, recycling, and management. Waste Manag. 2018, 78, 318-330. [CrossRef]

5. Hu, S.Y.; Dai, X.T.; Na, X.Z. Treatment process and comprehensive utilization of steel slag. Foundry Technol. $2019,40,109-113$.

6. Brand, A.S.; Fanijo, E.O. A Review of the Influence of Steel Furnace Slag Type on the Properties of Cementitious Composites. Appl. Sci. 2020, 10, 8210. [CrossRef]

7. Mason, B. The constitution of some open-heart slag. J. Iron Steel Inst. 1994, 11, 69-80.

8. Brand, A.S.; Roesler, J.R. Concrete with Steel Furnace Slag and Fractionated Reclaimed Asphalt Pavement; Illinois Center for Transportation: Urbana, IL, USA, 2014.

9. Brand, A.; Roesler, J.R. Interfacial transition zone of cement composites with steel furnace slag aggregates. Cem. Concr. Compos. 2018, 86, 117-129. [CrossRef]

10. Tossavainen, M.; Engstrom, F.; Yang, Q.; Menad, N.-E.; Larsson, M.L.; Bjorkman, B. Characteristics of steel slag under different cooling conditions. Waste Manag. 2007, 27, 1335-1344. [CrossRef] [PubMed]

11. Shi, C. Characteristics and cementitious properties of ladle slag fines from steel production. Cem. Concr. Res. 2002, 32, 459-462. [CrossRef]

12. Ghosh, S.N.; Chatterjee, A.K. Absorption and reflection infrared spectra of major cement minerals, clinkers and cements. J. Mater. Sci. 1974, 9, 1577-1584. [CrossRef]

13. Shen, W.; Cao, L.; Li, Q.; Zhang, W.; Wang, G.; Li, C. Quantifying $\mathrm{CO}_{2}$ emissions from China's cement industry. J. Renew. Sust. Energ. Rev. 2015, 50, 1004-1012. [CrossRef]

14. Liu, W.; Teng, L.; Rohani, S.; Qin, Z.; Zhao, B.; Xu, C.C.; Ren, S.; Liu, Q.; Liang, B. $\mathrm{CO}_{2}$ mineral carbonation using industrial solid wastes: A review of recent developments. Chem. Eng. J. 2021, 416, 129093. [CrossRef]

15. Mahoutian, M.; Ghouleh, Z.; Shao, Y. Synthesis of waste-based carbonation cement. Mater. Struct. 2016, 49, 4679-4690. [CrossRef]

16. Sanjuán, M.; Andrade, C.; Mora, P.; Zaragoza, A. Carbon Dioxide Uptake by Cement-Based Materials: A Spanish Case Study. Appl. Sci. 2020, 10, 339. [CrossRef]

17. Ibáñez, J.; Artús, L.; Cuscó, R.; López, Á.; Menéndez, E.; Andrade, M.C. Hydration and carbonation of monoclinic C2S and C3S studied by Raman spectroscopy. J. Raman Spectrosc. 2006, 38, 61-67. [CrossRef]

18. Wang, Q.Q.; Li, X.D.; Shen, X.D. Crystal structures of silicate minerals. J. Nanjing Tech. Univ. Nat. Sci. Ed. 2017, $39,39-45$.

19. Rejmak, P.; Dolado, J.S.; Aranda, M.A.G.; Ayuela, A. First-principles calculations on polymorphs of dicalcium silicate-Belite, a main component of portland cement. J. Phys. Chem. C. 2019, 123, 6768-6777. [CrossRef]

20. Kim, Y.J.; Nettleship, I.; Kriven, W.M. Phase Transformations in Dicalcium Silicate: II, TEM Studies of Crystallography, Microstructure, and Mechanisms. J. Am. Ceram. Soc. 1992, 75, 2407-2419. [CrossRef]

21. Ghosh, S.N.; Rao, P.B.; Paul, A.K.; Raina, K. The chemistry of dicalcium silicate mineral. J. Mater. Sci. 1979, 14, 1554-1566. [CrossRef]

22. Lai, G.C.; Nojiri, T.; Nakano, K. Studies of the stability of $\beta$-Ca2SiO4 doped by minor ions. Cem. Concr. Res. 1992, 22, 743-754. [CrossRef] 
23. Zhang, W.S.; Zhang, J.T.; Ye, J.Y.; Qian, J.S.; Shen, W.G.; Wang, Z.Y. Structure and activity of dicalcium silicate. J. Chin. Ceram. Soc. 2019, 368, 146-152.

24. Smith, D.K.; Majumdar, A.; Ordway, F. The crystal structure of $\gamma$-dicalcium silicate. Acta Crystallogr. 1965, 18, 787-795. [CrossRef]

25. Bredig, M.A. Polymorphism of Calcium Orthosilicate. J. Am. Ceram. Soc. 1950, 33, 188-192. [CrossRef]

26. Midgley, C.M. The crystal structure of $\beta$ dicalcium silicate. Acta Crystallogr. 1952, 5, 307-312. [CrossRef]

27. Durgun, E.; Manzano, H.; Kumar, P.V.; Grossman, J.C. The Characterization, Stability, and Reactivity of Synthetic Calcium Silicate Surfaces from First Principles. J. Phys. Chem. C 2014, 118, 15214-15219. [CrossRef]

28. De Leeuw, N.H.; Parker, S.C.; Catlow, C.R.A.; Price, G.D. Modelling the effect of water on the surface structure and stability of forsterite. Phys. Chem. Miner. 2000, 27, 332-341. [CrossRef]

29. Wang, Q.; Manzano, H.; Guo, Y.; Lopez-Arbeloa, I.; Shen, X. Hydration Mechanism of Reactive and Passive Dicalcium Silicate Polymorphs from Molecular Simulations. J. Phys. Chem. C 2015, 119, 19869-19875. [CrossRef]

30. Smith, R.S.; Li, Z.; Dohnalek, Z.; Kay, B.D.; Smith, S. Adsorption, Desorption, and Displacement $\mathrm{Kinetics}_{2}$ of $\mathrm{H}_{2} \mathrm{O}$ and $\mathrm{CO}_{2}$ on Forsterite, $\mathrm{Mg}_{2} \mathrm{SiO}_{4}$ (011). J. Phys. Chem. C 2014, 118, 29091-29100. [CrossRef]

31. Kwak, J.H.; Hu, J.Z.; Hoyt, D.W.; Sears, J.A.; Wang, C.; Rosss, K.M.; Felmy, A.R. Metal carbonation of forsterite in supercritical $\mathrm{CO}_{2}$ and $\mathrm{H}_{2} \mathrm{O}$ using solid state 29Si, 13C NMR spectroscopy. J. Phys. Chem. C. 2010, 114, 4126-4134. [CrossRef]

32. Wang, D.; Fang, Y.; Zhang, Y.; Chang, J. Changes in mineral composition, growth of calcite crystal, and promotion of physicochemical properties induced by carbonation of $\beta$-C2S. J. $\mathrm{CO}_{2}$ Util. 2019, 34, 149-162. [CrossRef]

33. Kerisit, S.; Bylaska, E.J.; Felmy, A.R. Water and carbon dioxide adsorption at olivine surfaces. Chem. Geol. 2013, 359, 81-89. [CrossRef]

34. Chang, J.; Fang, Y.; Shang, X. The role of $\beta-\mathrm{C} 2 \mathrm{~S}$ and $\gamma$-C2S in carbon capture and strength development. Mater. Struct. 2016, 49, 4417-4424. [CrossRef]

35. Ghouleh, Z.; Guthrie, R.I.; Shao, Y. High-strength KOBM steel slag binder activated by carbonation. Constr. Build. Mater. 2015, 99, 175-183. [CrossRef]

36. Mu, Y.D.; Xue, G.R.; Zhao, S.X.; Huang, X.; Wang, F.Z. Development of Carbonation of $\gamma$-Dicalcium Silicate. J. Chin. Ceram. Soc. 2017, 1197-1203.

37. Mu, Y.; Liu, Z.; Wang, F.; Huang, X. Carbonation characteristics of $\gamma$-dicalcium silicate for low-carbon building material. Constr. Build. Mater. 2018, 177, 322-331. [CrossRef]

38. Wang, D.; Chang, J. Comparison on accelerated carbonation of $\beta-\mathrm{C}_{2} \mathrm{~S}, \mathrm{Ca}(\mathrm{OH})_{2}$, and C4AF: Reaction degree, multi-properties, and products. Constr. Build. Mater. 2019, 224, 336-347. [CrossRef]

39. Goto, S.; Suenaga, K.; Kado, T.; Fukuhara, M. Calcium Silicate Carbonation Products. J. Am. Ceram. Soc. 1995, 78, 2867-2872. [CrossRef]

40. Bukowski, J.; Berger, R. Reactivity and strength development of $\mathrm{CO}_{2}$ activated non-hydraulic calcium silicates. Cem. Concr. Res. 1979, 9, 57-68. [CrossRef]

41. Gautier, M.; Poirier, J.; Bodénan, F.; Franceschini, G.; Véron, E. Basic oxygen furnace (BOF) slag cooling: Laboratory characteristics and prediction calculations. Int. J. Miner. Process. 2013, 123, 94-101. [CrossRef]

42. Choi, M.-w.; Jung, S.-M. Crystallization behavior of melted BOF slag during non-isothermal constant cooling process. J. Non-Cryst. Solids 2017, 468, 105-112. [CrossRef]

43. Engström, F.; Adolfsson, D.; Yang, Q.; Samuelsson, C.; Björkman, B. Crystallization Behaviour of some Steelmaking Slags. Steel Res. Int. 2010, 81, 362-371. [CrossRef]

44. Lin, Y.; Luo, Q.Y.; Yan, B.J.; Fabritius, T.; Shu, Q.F. Effect of $\mathrm{B}_{2} \mathrm{O}_{3}$ addition on mineralogical phases and leaching behavior of synthetic $\mathrm{CaO}-\mathrm{SiO}_{2}-\mathrm{MgO}-\mathrm{Al}_{2} \mathrm{O}_{3}-\mathrm{CrOx}$ slag. J. Mater. Cycles Waste Manag. 2020, 22, 1208-1217. [CrossRef]

45. Duée, C.; Bourgel, C.; Véron, E.; Allix, M.; Fayon, F.; Bodénan, F.; Poirier, J. Phosphorus speciation in dicalcium silicate phases: Application to the basic oxygen furnace (BOF) slag. Cem. Concr. Res. 2015, 73, 207-214. [CrossRef]

46. Wang, Y.C.; Luo, G.P.; Bai, J.B.; Hao, Z.Z.; Wu, H.L. Study on Influence of F, K and Na on Solid Phase Reaction of Sintering Process. Iron Steel 2008, 43, 12-15.

47. Sun, J.T.; Guo, X.M. Formation of Cuspidine and Action with Calcium Ferrite in Sintering Process of Fluorine-containing Iron Ores. Chin. J. Bioprocess Eng. 2017, 17, 565-570.

48. Hemalatha, M.; Santhanam, M. Characterizing supplementary cementing materials in blended mortars. Constr. Build. Mater. 2018, 191, 440-459. [CrossRef]

49. Shi, C.J.; Qian, J.S. High performance cementing materials from industrial slags—a review. Resour. Conserv. Recycl. 2000, 29, 195-207. [CrossRef]

50. Martins, A.C.P.; de Carvalho, J.M.F.; Costa, L.C.B.; Andrade, H.D.; de Melo, T.V.; Ribeiro, J.C.L.; Pedroti, L.G.; Peixoto, R.A.F. Steel slags in cement-based composites: An ultimate review on characterization, applications and performance. J. Constr. Build. Mater. 2021, 291, 123265. [CrossRef]

51. Shen, H.T.; Forssberg, E.; Nordström, U. Physicochemical and mineralogical properties of stainless steel slags oriented to metal recovery. Resour. Conserv. Recycl. 2004, 40, 245-271. [CrossRef]

52. Han, F.; Zhang, Z.; Wang, D.; Yan, P. Hydration heat evolution and kinetics of blended cement containing steel slag at different temperatures. Thermochim. Acta 2015, 605, 43-51. [CrossRef] 
53. de Carvalho, J.M.F.; de Melo, T.V.; Fontes, W.C.; dos Santos Batista, J.O.; Brigolini, G.J.; Peixoto, R.A.F. More eco-efficient concrete: An approach on optimization in the production and use of waste-based supplementary cementing materials. Constr. Build. Mater. 2019, 206, 397-409. [CrossRef]

54. Borosnyói, A. Long term durability performance and mechanical properties of high performance concretes with combined use of supplementary cementing materials. Constr. Build. Mater. 2016, 112, 307-324. [CrossRef]

55. Li, W.F. Research on physicochemical properties and resource utilization of converter slag. Beijing Univ. Chem. Technol. 2008.

56. Wu, J.; Zhu, Y.-J.; Chen, F.; Zhao, X.-Y.; Zhao, J.; Qi, C. Amorphous calcium silicate hydrate/block copolymer hybrid nanoparticles: Synthesis and application as drug carriers. Dalton Trans. 2013, 42, 7032-7040. [CrossRef] [PubMed]

57. Tu, K.; Liu, J.X.; Deng, K. Study of the hydration behaviour of steel slag and steel slag cement complex powders. J. Beijing Univ. Chem. Technol. Nat. Sci. Ed. 2015, 42, 62-68.

58. Wang, Q.; Yan, Y.P. Characteristics of hydration products of steel slag. J. Chin. Ceram. Soc. 2010, 38, 1731-1734.

59. Wang, Q.; Yan, Y.P. Hydration properties of basic oxygen furnace steel slag. Const. Build. Mater. 2010, 24, 1134-1140. [CrossRef]

60. Liu, J.; Yu, B.; Wang, Q. Application of steel slag in cement treated aggregate base course. J. Clean Prod. 2020, $269,121733$. [CrossRef]

61. Samad, S.; Shah, A.; Limbachiya, M.C. Strength development characteristics of concrete produced with blended cement using ground granulated blast furnace slag (GGBS) under various curing conditions. Sadhana 2017, 42, 1203-1213. [CrossRef]

62. Tsakiridis, P.E.; Papadimitriou, G.D.; Tsivilis, S.; Koroneos, C. Utilization of steel slag for Portland cement clinker production. J. Hazard. Mater. 2008, 152, 805-811. [CrossRef] [PubMed]

63. Zhuang, S.; Wang, Q. Inhibition mechanisms of steel slag on the early-age hydration of cement. Cem. Concr. Res. 2020, 140, 106283. [CrossRef]

64. Liu, S.; Wang, Z.; Li, X. Long-term properties of concrete containing ground granulated blast furnace slag and steel slag. Mag. Concr. Res. 2014, 66, 1095-1103. [CrossRef]

65. Wang, Q.; Yan, P.; Han, S. The influence of steel slag on the hydration of cement during the hydration process of complex binder. Sci. China Technol. Sci. 2011, 54, 388-394. [CrossRef]

66. Jiang, Y.; Ling, T.-C.; Shi, C.; Pan, S.-Y. Characteristics of steel slags and their use in cement and concrete-A review. Resour. Conserv. Recycl. 2018, 136, 187-197. [CrossRef]

67. Sun, J. Study of effects of ground steel slag on mechanical performance and soundness of concrete. Coal Ash China 2003, 15, 7-9.

68. Wang, Y.B.; He, X.Y.; Su, Y.; Yang, J.; Strnadel, B.; Wang, X.J. Efficiency of wet-grinding on the mechanochemical activation of granulated blast furnace slag (GBFS). Constr. Build. Mater. 2019, 199, 185-193. [CrossRef]

69. Kriskova, L.; Pontikes, Y.; Cizer, Ö.; Mertens, G.; Veulemans, W.; Geysen, D.; Jones, P.T.; Vandewalle, L.; Balen, K.V.; Blanpain, B. Effect of mechanical activation on the hydraulic properties of stainless steel slags. Cem. Concr. Res. 2012, 42, 778-788. [CrossRef]

70. Wang, K.X.; Long, H.M.; Meng, Q.M.; Wei, R.F.; Zhang, H. Steel slag cementitious activity and mechanism based on physical excitation. Iron Steel 2018, 53, 82-86.

71. Zhao, F.C.; Ju, J.T.; Liao, J.K.; Kong, W.M.; Dang, Y.J. Analysis of comprehensive utilization and basic properties of converter slag processed. J. Iron Steel Res. 2013, 25, 23-28.

72. Tang, M.S.; Yuan, M.X.; Shen, X. The crystalline state of Mg, FeO and $\mathrm{MnO}$ in steel slag and the soundness of steel slag cement. J. Chin. Ceram. Soc. 1979, 7, 35-46.

73. Zhang, L.J.; Wu, H.Z.; Ye, Z.M.; Liu, M.; Ding, L.; Chang, J. Steel slag carbonation by orthogonal experimentt. J. Iron Steel Res. 2009, 23, 127-230.

74. Liu, S.; Li, L. Influence of fineness on the cementitious properties of steel slag. J. Therm. Anal. Calorim. 2014, 117, 629-634. [CrossRef]

75. Khan, K.; Amin, M.N. Influence of fineness of volcanic ash and its blends with quarry dust and slag on compressive strength of mortar under different curing temperatures. Constr. Build. Mater. 2017, 154, 514-528. [CrossRef]

76. Dai, J.; Wang, Q.; Xie, C.; Xue, Y.; Duan, Y.; Cui, X. The effect of fineness on the hydration activity index of ground granulated blast furnace slag. Materials 2019, 12, 2984. [CrossRef]

77. Shi, Y.; Chen, H.; Wang, J.; Feng, Q. Preliminary investigation on the pozzolanic activity of superfine steel slag. Constr. Build. Mater. 2015, 82, 227-234. [CrossRef]

78. Wang, Q.; Yang, J.; Yan, P. Cementitious properties of super-fine steel slag. Powder Technol. 2013, 245, 35-39. [CrossRef]

79. Zhu, X.; Hou, H.; Huang, X.; Zhou, M.; Wang, W. Enhance hydration properties of steel slag using grinding aids by mechanochemical effect. Constr. Build. Mater. 2012, 29, 476-481. [CrossRef]

80. Jha, V.; Kameshima, Y.; Nakajima, A.; Okada, K. Hazardous ions uptake behavior of thermally activated steel-making slag. J. Hazard. Mater. 2004, 114, 139-144. [CrossRef]

81. Yan, P.Y.; Wang, Q. Effect of high temperature curing on the early hydration characteristics of a complex binder containing steel slag. J. Tsinghua Univ. Sci. Technol. 2009, 49, 790-793.

82. Feng, J.; Sun, J. A comparison of the 10-year properties of converter steel slag activated by high temperature and an alkaline activator. Constr. Build. Mater. 2019, 234, 116948. [CrossRef]

83. Shirani, S.; Cuesta, A.; Morales-Cantero, A.; De la Torre, A.G.; Olbinado, M.P.; Aranda, M.A.G. Influence of curing temperature on belite cement hydration: A comparative study with Portland cement. Cem. Concr. Res. 2021, 147, 106499. [CrossRef] 
84. Liu, Q.; Liu, J.; Qi, L. Effects of temperature and carbonation curing on the mechanical properties of steel slag-cement binding materials. Constr. Build. Mater. 2016, 124, 999-1006. [CrossRef]

85. Sun, J.; Chen, Z. Effect of silicate modulus of water glass on the hydration of alkali-activated converter steel slag. J. Therm. Anal. Calorim. 2019, 138, 47-56. [CrossRef]

86. Wang, Q.; Yan, P.Y.; Feng, J.W. A discussion on improving hydration activity of steel slag by altering its mineral compositions. J. Hazard. Mater. 2011, 186, 1070-1075. [CrossRef] [PubMed]

87. Ashraf, W. Microstructure of chemically activated gamma-dicalcium silicate paste. Constr. Build. Mater. 2018, 185, 617-627. [CrossRef]

88. Liu, Z.; Zhang, D.-W.; Li, L.; Wang, J.-X.; Shao, N.-N.; Wang, D.-M. Microstructure and phase evolution of alkali-activated steel slag during early age. Constr. Build. Mater. 2019, 204, 158-165. [CrossRef]

89. Sun, J.; Zhang, Z.; Zhuang, S.; He, W. Hydration properties and microstructure characteristics of alkali-activated steel slag. Constr. Build. Mater. 2020, 241, 118141. [CrossRef]

90. Liu, B.; Luo, G.; Xie, Y. Effect of curing conditions on the permeability of concrete with high volume mineral admixtures. Constr. Build. Mater. 2018, 167, 359-371. [CrossRef]

91. Amin, M.S.; El-Gamal, S.M.A.; Abo-El-Enein, S.A.; El-Hosiny, F.I.; Ramadan, M. Physico-chemical characteristics of blended cement pastes containing electric arc furnace slag with and without silica fume. HBRC J. 2015, 11, 321-327. [CrossRef]

92. Hekal, E.E.; Abo-El-Enein, S.A.; Elkorashy, S.A.; Megahed, G.M.; El-Sayed, T.M. Hydration characteristics of Portland cementElectric arc furnace slag blends. HBRC J. 2013, 9, 118-124. [CrossRef]

93. Roslan, N.H.; Ismail, M.; Abdul-Majid, Z.; Ghoreishiamiri, S.; Muhammad, B. Performance of steel slag and steel sludge in concrete. Constr. Build. Mater. 2016, 104, 16-24. [CrossRef]

94. Zhang, X.; Zhao, S.; Liu, Z.; Wang, F. Utilization of steel slag in ultra-high performance concrete with enhanced eco-friendliness. Constr. Build. Mater. 2019, 214, 28-36. [CrossRef]

95. Gao, T.M.; Dai, T.; Shen, L.; Jiang, L. Benefits of using steel slag in cement clinker production for environmental conservation and economic revenue generation. J. Clean. Prod. 2021, 282, 124538. [CrossRef]

96. Li, Q.; Zhang, L.; Gao, X.; Zhang, J. Effect of pulverized fuel ash, ground granulated blast-furnace slag and $\mathrm{CO}_{2}$ curing on performance of magnesium oxysulfate cement. Constr. Build. Mater. 2019, 230, 116990. [CrossRef]

97. Jang, J.G.; Lee, H.K. Microstructural densification and CO2 uptake promoted by the carbonation curing of belite-rich Portland cement. Cem. Concr. Res. 2016, 82, 50-57. [CrossRef]

98. Bertos, M.F.; Simons, S.J.R.; Hills, C.D.; Carey, P.J. A review of accelerated carbonation technology in the treatment of cement-based materials and sequestration of $\mathrm{CO}_{2}$. J. Hazard. Mater. 2004, 112, 193-205. [CrossRef]

99. Wang, L.; Chen, L.; Tsang, D.C.W.; Li, J.S.; Yeung, T.L.Y.; Ding, S.M.; Poon, C.S. Green remediation of contaminated sediment by stabilization/solidification with industrial by-products and $\mathrm{CO}_{2}$ utilization. Sci. Total Environ. 2018, 631, 1321-1327. [CrossRef] [PubMed]

100. Mo, L.; Zhang, F.; Deng, M. Mechanical performance and microstructure of the calcium carbonate binders produced by carbonating steel slag paste under $\mathrm{CO}_{2}$ curing. Cem. Concr. Res. 2016, 88, 217-226. [CrossRef]

101. Gruyaert, E.; Van den Heede, P.; De Belie, N. Carbonation of slag concrete: Effect of the cement replacement level and curing on the carbonation coefficient-Effect of carbonation on the pore structure. Cem. Concr. Compos. 2013, 35, 39-48. [CrossRef]

102. Sanjuán, M.; Estévez, E.; Argiz, C. Carbon Dioxide Absorption by Blast-Furnace Slag Mortars in Function of the Curing Intensity. Energies 2019, 12, 2346. [CrossRef]

103. De Belie, N.; Kratky, J.; Van Vlierberghe, S. Influence of pozzolans and slag on the mi-crostructure of partially carbonated cement paste by means of water vapour and nitrogen sorption experiments and BET calculations. Cem. Concr. Res. 2010, 40, 1723-1733. [CrossRef]

104. Tran, D.; Lee, Y.; Lee, H.; Yang, H.-M.; Singh, J. Effects of $\gamma-\mathrm{C}_{2} \mathrm{~S}$ on the Properties of Ground Granulated Blast-Furnace Slag Mortar in Natural and Accelerated Carbonation Curing. Sustainability 2021, 13, 357. [CrossRef]

105. Teir, S.; Eloneva, S.; Fogelholm, C.-J.; Zevenhoven, R. Dissolution of steelmaking slags in acetic acid for precipitated calcium carbonate production. Energy 2007, 32, 528-539. [CrossRef]

106. Chen, Z.; Li, R.; Zheng, X.; Liu, J. Carbon sequestration of steel slag and carbonation for activating RO phase. Cem. Concr. Res. 2020, 139, 106271. [CrossRef]

107. Stolaroff, J.K.; Lowry, G.V.; Keith, D.W. Using CaO- and MgO-rich industrial waste streams for carbon sequestration. Energy Conv. Manag. 2005, 46, 687-699. [CrossRef]

108. Wang, J.; Zhong, M.; Wu, P.; Wen, S.; Huang, L.; Ning, P. A Review of the Application of Steel Slag in $\mathrm{CO}_{2}$ Fixation. ChemBioEng Rev. 2021. [CrossRef]

109. Huijgen, W.J.J.; Ruijg, G.J.; Comans, R.N.J.; Witkamp, G.-J. Energy Consumption and $\mathrm{Net}^{\mathrm{CO}_{2}}$ Sequestration of Aqueous Mineral Carbonation. Ind. Eng. Chem. Res. 2006, 45, 9184-9194. [CrossRef]

110. Tian, S.; Jiang, J.; Chen, X.; Yan, F.; Li, K. Direct Gas-Solid Carbonation Kinetics of Steel Slag and the Contribution to In situ Sequestration of Flue Gas $\mathrm{CO}_{2}$ in Steel-Making Plants. ChemSusChem 2013, 6, 2348-2355. [CrossRef]

111. Barella, S.; Gruttadauria, A.; Magni, F.; Mapelli, C.; Mombelli, D. Survey about Safe and Reliable Use of EAF Slag. ISIJ Int. 2012, 52, 2295-2302. [CrossRef] 
112. Baciocchi, R.; Costa, G.; Polettini, A.; Pomi, R. Effects of thin-film accelerated carbonation on steel slag leaching. J. Hazard. Mater. 2015, 286, 369-378. [CrossRef]

113. Li, J.-L.; Zhang, H.-N.; Xu, A.-J.; Cui, J.; He, D.-F.; Tian, N.-Y. Theoretical and Experimental on Carbon Dioxide Sequestration Degree of Steel Slag. J. Iron Steel Res. Int. 2012, 19, 29-32. [CrossRef]

114. Tu, M.X.; Lei, Z.; Lv, X.F.; Zhao, H.X.; Wang, L.N.; Zhang, J.L.; Chen, D.S.; Song, W.W.; Qi, T. Carbon dioxide sequestration using water quenched steel slag. Chin. J. Environ. Eng. 2015, 9, 4514-4518.

115. Yu, J.; Wang, K. Study on Characteristics of Steel Slag for $\mathrm{CO}_{2}$ Capture. Energy Fuels 2011, 25, 5483-5492. [CrossRef]

116. Huijgen, W.J.; Witkamp, G.J.; Comans, R.N.J. Mineral $\mathrm{CO}_{2}$ Sequestration by Steel Slag Carbonation. Environ. Sci. Technol. 2005, 39, 9676-9682. [CrossRef] [PubMed]

117. Huijgen, W.J.J.; Comans, R.N.J. Carbonation of Steel Slag for $\mathrm{CO}_{2}$ Sequestration: Leaching of Products and Reaction Mechanisms. Environ. Sci. Technol. 2006, 40, 2790-2796. [CrossRef]

118. Wang, Y.-J.; Zeng, Y.-N.; Li, J.-G.; Zhang, Y.-Z.; Zhang, Y.-J.; Zhao, Q.-Z. Carbonation of argon oxygen decarburization stainless steel slag and its effect on chromium leachability. J. Clean. Prod. 2020, 256, 120377. [CrossRef]

119. Jo, H.; Lee, M.G.; Park, J.; Jung, K.D. Preparation of high-purity nano-CaCO 3 from steel slag. Energy 2017, 120, 884-894. [CrossRef]

120. Eloneva, S.; Teir, S.; Salminen, J.; Fogelholm, C.-J.; Zevenhoven, R. Steel Converter Slag as a Raw Material for Precipitation of Pure Calcium Carbonate. Ind. Eng. Chem. Res. 2008, 47, 7104-7111. [CrossRef] 